\title{
Uji Aktivitas Antijamur Pada Minyak Nilam Hasil Destilasi dan Fraksinasi Terhadap Jamur $C$. ALBICANS DAN T. MENTAGROPHYTES
}

Activities Test Antifungal C. Albicans and T. Mentagrophytes on Patchouli oil from Destilation and Factination

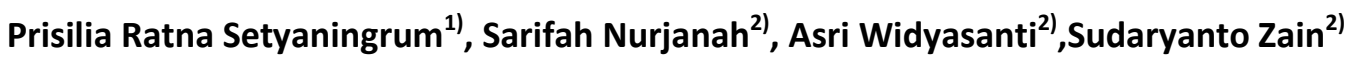 \\ ${ }^{1)}$ Alumnus Departemen Teknik Pertanian dan Biosistem, Universitas Padjadjaran \\ ${ }^{2)}$ Staff Departemen Teknik dan Biosistem, Fakultas Teknologi Industri Pertanian, Universitas Padjadjaran \\ Jl. Raya Bandung Sumedang KM 21, Jatinangor 40600 \\ Email : prisilia.ratna@gmail.com
}

\begin{abstract}
ABSTRAK
Senyawa patchouli alcohol (PA) pada minyak nilam diduga memiliki fungsi sebagai agen antijamur. Penelitian ini bertujuan untuk mengetahui pengaruh fraksinasi pada aktivitas antijamur miyak nilam. Minyak nilam yang diujikan: minyak nilam tanpa fraksinasi (100; Kadar PA: 35,28\%), minyak nilam fraksi 2 (F2; Kadar PA: 25,62\%), minyak nilam fraksi 7 (F7; Kadar PA: 34,86\%), dan minyak nilam fraksi 8 (F8; Kadar PA: 54,59\%). Minyak nilam ini diujikan pada Candida albicans dan Trichophyton mentagrophytes. Penelitian eksperimental ini dilakukan dengan metode difusi agar yang diulang sebanyak 3 kali. Hasil kemudian dianalisis dengan Rancangan Acak Lengkap Faktorial dan diuji lanjut dengan Uji Dunnet dan Uji Duncan. Hasil penelitian menunjukkan keempat jenis minyak nilam memiliki aktivitas antijamur terhadap kedua jenis jamur. Pada jamur C. albicans, DDH (diameter daya hambat) terluas pada ukuran 9,24 mm (F8) dan DDH terkecil senilai 5,89 mm (F2). Pada jamur T. mentagrophytes, DDH terluasnya adalah 7,70 mm (F8). DDH terkecilnya senilai 6,18 mm (F2). Dari hasil dapat dilihat bahwa fraksinasi minyak memengaruhi aktivitas antijamur, dimana ukuran DDH yang dihasilkan berbanding lurus dengan kadar patchouli alcohol dari minyak tersebut. Sehingga, minyak nilam dengan aktivitas antijamur terbaik adalah minyak nilam dengan kadar PA tertinggi, yaitu minyak nilam fraksi 8.
\end{abstract}

Kata kunci : antijamur, fraksinasi, minyak nilam, patchouli alcohol.

\begin{abstract}
Patchouli alcohol (PA) on patchouli oil was suspected to be an antifungal agent. This research was aimed to determine influance of fractionation to patchouli oil's antifungal activitiy. Patchouli oil that being used were: patchouli oil without fractionation (100; PA: 35.28\%), patchouli oil fractions 2 (F2; PA: 25.62\%), patchouli oil fractions 7 (F7; PA: 34.86\%), and patchouli fraction 8 (F8; PA: 55.59\%). Patchouli oil was tested against Candida albicans and Trichophyton mentagrophytes. This experimental research was done by using agar diffusion method with holes and repeated 3 times. The results were analyzed using completely randomized factorial design followed by Dunnet test and Duncan Test. The results showed that the four patchouli oil types did have antifungal activity against both types of fungi. On C. albicans, the biggest inhibiton diameter sizes was $9.24 \mathrm{~mm}$ (F8) and the smallest was $5.89 \mathrm{~mm}$ (F2). While on T. mentagrophytes, the biggest was $7.70 \mathrm{~mm}$ (F8) and the smallest was $6.18 \mathrm{~mm}$ (F2). The results showed that fractionation was indeed influencing antifungal activity. The inhibition zone size was proportional to the patchouli alcohol content. Therefore, patchouli oil with the best antifungal activity was the one with the highest patchouli content, and that was F8.
\end{abstract}

Keywords : antifungal, fractionation, patchouli oil, patchouli alcohol.

Diterima : 10 Februari 2017; Disetujui : 20 Maret 2017; Online Published : 25 Juli 2017

DOI : 10.24198/jt.vol11n1.9

Uji Aktivitas Antijamur Pada Minyak Nilam Hasil Destilasi dan Fraksinasi Terhadap Jamur C. Albicans 


\section{PENDAHULUAN}

Salah satu manfaat dari minyak atsiri adalah sebagai bakterisida dan fungisida. Fungisida diperlukan karena terdapat beberapa jenis jamur seperti Candida albicans dan Trichophyton mentagrophytes yang merupakan jamur patogen yang umum menyebabkan infeksi pada manusia. C. albicans adalah fungi patogen oportunistik yang menyebabkan berbagai penyakit pada manusia candidiasis (Kusumaningtyas, 2006). Sedangkan T. mentagrophytes merupakan salah satu genus jamur yang menyebabkan dermatofitosis (Jawetz, dkk., 2010). Martinez-rossi, dkk. (2008) menjelaskan bahwa meskipun sudah banyak obat antijamur yang berkembang selama beberapa dekade (contoh: Nystatin dan Fluconazole), obatobat tersebut terbatas hanya pada beberapa kelas kimia saja. Selain itu, terjadinya resistansi akan isolasi klinik menyebabkan gagalnya pengobatan penyakit jamur. Karenanya dibutuhkan perkembangan dan generasi baru dari antijamur yang berspektrum luas yang selektif terhadap sel jamur target tanpa efek samping permanen pada manusia yang dijangkitinya.

Minyak nilam telah banyak digunakan di bidang kosmetik, industri parfum dan industri farmasi. Minyak nilam memiliki berbagai aktivitas farmakologi yang beragam seperti sebagai antidepresan, anti-radang, antijamur, antiseptic, dan obat penenang (Das, dkk., 2011). Minyak atsiri dalam sel sekresi dapat menyebabkan proses lisis pada sel-sel sekitarnya, dan menyebabkan proses metabolisme abnormal, sehingga membentuk lapisan gabus atau lapisan lendir dengan daya permeabililtas yang rendah terhadap minyak atsiri (Guenther, dkk., 2006).

Pada penelitian Aisyah, dkk (2008) mengenai sifat antimikroba dari minyak nilam, didapatkan hasil yang lebih spesifik mengenai aktivitas antimikroba pada minyak nilam, yaitu kristal patchouli alkohol (kadar patchouli alcohol: 87,36\%) lebih aktif penghambatannya terhadap mikrobia uji dibandingkan dengan minyak nilam (kadar kadar patchouli alcohol: $32,60 \%)$.Karenanya, diperlukan proses peningkatan kadar patchouli alcohol pada minyak nilam untuk mendapatkan potensi aktivitas antimikroba yang optimal.

Salah satu cara untuk meningkatkan kadar patchouli alcohol pada minyak nilam adalah dengan fraksinasi. Fraksinasi atau penyulingan fraksi merupakan salah satu proses yang berguna untuk memisahkan minyak atsiri menjadi beberapa fraksi berdasarkan perbedaan titik didih dan baunya (Guenther, dkk., 2006). Oleh karena itu penelitian ini dilakukan untuk melihat perbandingan aktivitas antijamur pada minyak nilam hasil destilasi dan minyak nilam hasil fraksinasi yang memiliki kandungan patchouli alcohol yang berbeda.

\section{METODOLOGI PENELITIAN}

Penelitian ini dilakukan pada bulan Juli 2016 hingga bulan Januari 2017 bertempat di Laboratorium Riset dan Pengujian Bioteknologi Fakultas Peternakan, Laboratorium Kimia Pangan, dan Laboratorium Pasca Panen dan Teknologi Proses Fakultas Teknologi Industri Pertanian Universitas Padjadjaran.Bahan utama yang digunakan pada penelitian ini adalah minyak nilam yang didapat dari Aceh. Jenis minyak nilam yang dipakai adalah minyak nilam hasil destilasi murni $(100 \%)$ dan minyak nilam hasil fraksinasi (minyak nilam fraksi 2, 7, dan 8). Bahan kimia penunjang yang digunakan antara lain adalah aquades, alkohol 90\%, fenolftalein, Kalium Hidroksida $(\mathrm{KOH})$ $0,1 \mathrm{~N}$ dan $0,5 \mathrm{~N}$, Asam Klorida $(\mathrm{HCl}) 0,5 \mathrm{~N}, \mathrm{NaCl}$ fisiologis $0,85 \%, \mathrm{BaCl} 21 \%, \mathrm{H}_{2} \mathrm{SO}_{4} 1 \%$, dan spiritus. Jamur yang akan digunakan adalah $\mathrm{C}$. albicansdan T. Mentagrophytes yang didapat dari Laboratorium Mikrobiologi, Fakultas Farmasi, Institut Teknologi Bandung. Media pembenihan yang digunakan yaitu Sabouraud Dextrose Agar (SDA). Sedangkan alat yang digunakan dalam penelitian ini yaitu pipet tetes, chromameter, timbangan analitik, piknometer, refraktometer $\mathrm{ABBE}$, condenser leg, heating mantle, pipet volumetrik, buret, oven, beaker glass, hot plate stirrer, autoklaf, tabung reaksi, jarum ose, bunsen, spirtus, vortex mixer, spektrofotometer, cuvet, cawan petri, mikropipet, yellowtip, bleutip, glass spreader, perforator agar, inkubator, jangka sorong. 
Parameter yang diamati pada penelitian ini adalah karakteritik dan aktivitas antijamur dari keempat jenis minyak nilam. Karakteristik yang diidentifikasi meliputi warna, bobot jenis, indeks bias, kelarutan dalam alkohol 90\%, bilangan asam, bilangan ester, putaran optik dan kadar patchouli alcohol. Sedangkan pada pengamatan aktivitas antijamur, yang diamati adalah Diameter Daya Hambat (DDH).

Metode penelitian yang digunakan adalah metode eksperimental dengan menggunakan analisis Rancangan Acak Lengkap (RAL) faktorial dengan 2 faktor. Faktor pertama adalah jenis minyak nilam beserta larutan kontrol (positif dan negatif) yang akan diujikandan faktor kedua adalah jenis jamur yang diujikan yaitu $C$. albicans dan $T$. mentagrophytes. Kombinasi dari kedua faktor ini akan diulang sebanyak 3 kali. Jika terdapat perbedaan yang nyata pada faktor-faktor tersebut, maka dilakukan uji lanjutan dengan uji Dunnet dan uji Duncan dengan taraf kepercayaan 95\% dan 99\%.Dari hasil pengujian lanjutan dapat dilihat kombinasi faktor mana yang memiliki perbedaan yang signifikan serta perbandingannya dengan zat kontrol positif yang digunakan dalam pengujian. Berikut adalah diagram alir pengujian aktivitas antijamur dengan menggunakan metode sumuran (Gambar 1).

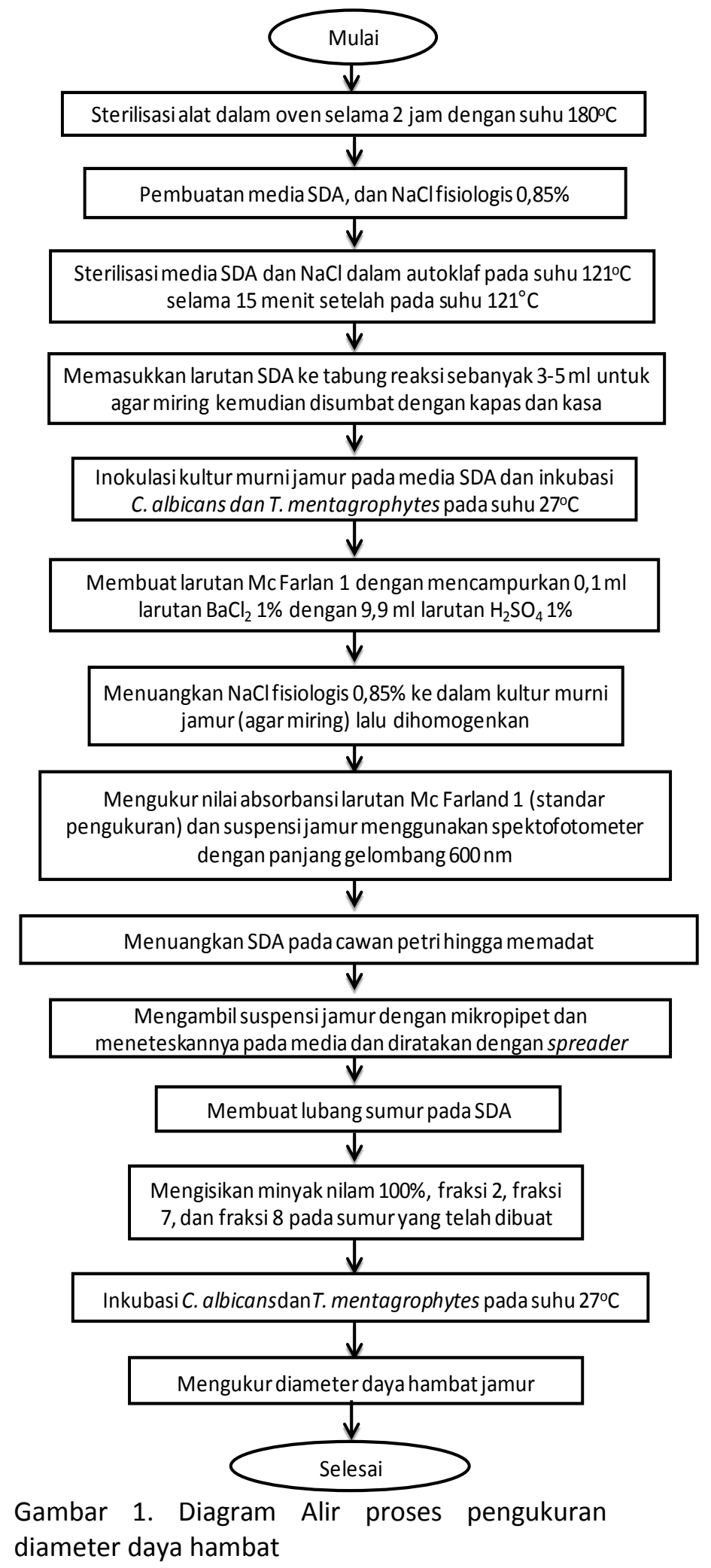

Gambar 1. Diagram Alir proses pengukuran diameter daya hambat

\section{HASIL DAN PEMBAHASAN}

Uji Aktivitas Antijamur Pada Minyak Nilam Hasil Destilasi dan Fraksinasi Terhadap Jamur C. Albicans 


\section{Uji Karakteristik Minyak Nilam}

Pengujian karakteristik dilakukan untuk mengetahui kualitas dari setiap jenis minyak dan melihat pengaruhnya terhadap aktivitas antijamur yang dmiliki. Hasil uji karakteristik fisik dan kimia sampel minyak nilam yang diujikan kemudian dibandingkan dengan mutu minyak nilam pada SNI 06-2385-2006. Data hasil uji mutu minyak nilam disajikan pada Tabel 1.

Tabel 1. Mutu Minyak Nilam

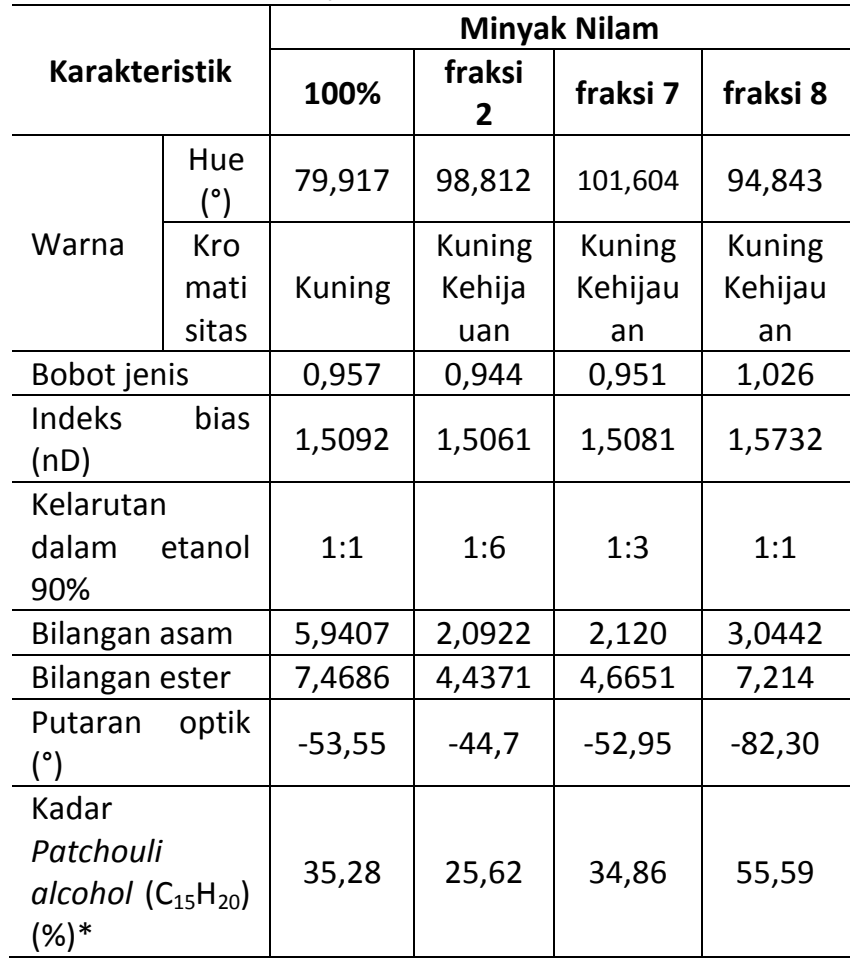

Berdasarkan parameter warna yang diujikan, dapat terlihat bahwa semua jenis minyak nilam yang diujikan, meskipun memiliki nilai Hue yang berbeda tetapi termasuk kedalam range warna yang sama, yaitu kuning hingga kuning kehijauan. Hal ini menunjukkan bahwa keempat minyak atsiri tersebut memenuhi SNI minyak nilam yang memiliki standar warna kuning muda hingga coklat kemerahan. Hasil pengukuran warna dapat dilihat pada Tabel 2.

Tabel 2. Hasil pengukuran warna minyak nilam

\begin{tabular}{c|c|c}
\hline Minyak & Parameter Warna & Warna \\
\hline
\end{tabular}

\begin{tabular}{c|c|c|c|c|c|c}
\hline NIlam & $\mathbf{L}^{*}$ & $\mathbf{a}^{*}$ & $\mathbf{b}^{*}$ & $\mathbf{C}$ & Hue & \\
\hline $100 \%$ & $\begin{array}{c}74, \\
64\end{array}$ & 20,57 & $\begin{array}{c}115, \\
68\end{array}$ & 117,49 & $\begin{array}{c}79, \\
92\end{array}$ & Kuning \\
\hline Fraksi 2 & $\begin{array}{c}92, \\
16\end{array}$ & $-8,83$ & $\begin{array}{c}56, \\
96\end{array}$ & 57,64 & $\begin{array}{c}98, \\
81\end{array}$ & $\begin{array}{c}\text { Kuning } \\
\text { Kehijau } \\
\text { an }\end{array}$ \\
\hline Fraksi 7 & $\begin{array}{c}92, \\
92\end{array}$ & $\begin{array}{c}- \\
\text { Fraksi } 8\end{array}$ & $\begin{array}{c}50, \\
26\end{array}$ & 51,3 & $\begin{array}{c}101 \\
, 60\end{array}$ & $\begin{array}{c}\text { Kuning } \\
\text { Kehijau } \\
\text { an }\end{array}$ \\
\hline 69 & $-5,68$ & $\begin{array}{c}72, \\
45\end{array}$ & 72,67 & $\begin{array}{c}94, \\
84\end{array}$ & $\begin{array}{c}\text { Kuning } \\
\text { Kehijau } \\
\text { an }\end{array}$ \\
\hline
\end{tabular}

Arpi dkk. (2011) dalam penelitiannya menjelaskan bahwa minyak nilam dengan waktu destilasi atau waktu proses yang lebih lama dan kenaikan temperatur pada proses akan meningkatkan berat fraksi yang akhirnya menyebabkan warna dari minyak nilam yang dihasilkan akan semakin menggelap. Pada Tabel 7 dapat dilihat bahwa fraksi 8 , yang dihasilkan dari proses destilasi fraksinasi dengan temperatur tertinggi dan waktu terlama, memiliki nilai Hue yang terendah dengan nilai $L^{*}$ (kecerahan) yang paling rendah pula jika dibandingkan dengan minyak hasil fraksinasi lainnya, yaitu senilai $94,843^{\circ}$ dan 82,69 .

Nilai bobot jenis yang dijadikan standar oleh SNI yaitu sebesar 0,950-0,975. Guenther (2006) menyatakan bahwa, semakin besar fraksi berat yang terkandung dalam minyak, maka semakin besar pula nilai bobot jenisnya. Semakin besar nilai bobot jenis maka komponen yang terkandung di dalam zat tersebut semakin banyak dengan berat molekul yang tinggi dan rantai karbon yang panjang.Patchouli alcohol merupakan salah satu komponen hidrogen teroksigenisasi yang memiliki bobot jenis yang lebih besar jika dibandingkan dengan hidrokarbon yang tak teroksigenisasi. Karenanya, dari hasil pengamatan yang dilakukan, didapatkan hasil bahwa Fraksi 8 dengan kandungan patchouli alcohol tertinggi memiliki nilai bobot jenis tertinggi jika dibandingkan dengan ketiga jenis minyak lainnya, yaitu sebesar 1,026. Sedangkan minyak nilam fraksi 2 dengan kandungan patchouli alcohol terendah, memiliki nilai bobot jenis terkecil yaitu sebesar 0,944. Sedangkan bobot jenis minyak nilam $100 \%$ dan 
minyak nilam fraksi 7 secara berturut-turut adalah sebesar 0,957 dan 0,951.

Semakin tinggi komponen berantai panjang seperti seskuiterpen atau komponen bergugus oksigen pada minyak nilam membuat nilai indeks bias menjadi besar (Armando, 2009). Patchouli alcohol merupakan senyawa yang termasuk dalam golongan sesquiterpen. Perbedaan nilai indeks bias ini diduga karena adanya perbedaan pada kandungan patchouli alcohol pada minyak nilam. Minyak nilam dengan nilai indeks bias tertinggi merupakan minyak nilam fraksi 8 dengan nilai 1,5732, kemudian diikuti dengan minyak nilam $100 \%(1,5092)$, minyak nilam fraksi 7 (1,5081), dan nilai indeks bias terkecil dimiliki oleh minyak fraksi 2 dengan nilai indeks bias sebesar 1,5061.

Minyak atsiri yang kaya akan komponen teroksigenasi lebih mudah larut dalam alkohol daripada komponen yang kaya akan terpen. Semakin kecilnya nilai kelarutan menandakan bahwa komponen minyak nilam didominasi oleh komponen hidrokarbon teroksigenasi dibandingkan dengan komponen terpen (Guenther, 2006). Patchouli alcohol merupakan salah satu komponen hidrokarbon teroksigenisasi pada minyak nilam, sehingga besarnya kandungan patchouli alkohol dan dan hidrokarbon teroksigenisasi lain berpengaruh pada nilai kelarutan dalam alkohol pada minyak yang diujikan. Minyak nilam 100\% dan minyak nilam fraksi 8 dan mminyak ni,lam 100\% memiliki nilai perbandingan kelarutan paling rendah, yaitu hanya sebesar 1:1 saja jika dibandingkan dengan jenis minyak lainnya. Minyak nilam fraksi 7 memiliki perbandingan sebesar 1:3. Sedangkan minyak nilam fraksi 2 dengan kandungan patchouli alcohol terkecil terlihat lebih sulit larut jika dibandingkan dengan tiga jenis minyak lainnya, dengan perbandingan sebesar 1:6.

Guenther (2006) menyatakan bahwa bilangan asam suatu minyak bertambah akibat dari oksidasi aldehid dan hidrolisa ester.Armando (2009) menambahkan, selain kontak langsung dengan udara, proses oksidasi juga bisa disebabkan oleh tekanan dan temperatur yang tinggi pada proses pembuatan minyak. Hal ini dapat dilihat pada tingginya nilai bilangan asam pada minyak nilam fraksi 8 jika dibandingkan dengan minyak nilam hasil fraksinasi yang lainnya, yaitu sebesar 3,0442 . Tingginya nilai bilangan asam pada minyak nilam fraksi 8 ini diduga karena minyak nilam fraksi 8 dihasilkan dari proses fraksinasi dengan temperatur dan tekanan yang lebih tinggi dibandingkan dengan minyak nilam fraksi $2(2,0922)$ dan minyak nilam fraksi 7 $(2,1201)$.

Waktu proses destilasi yang lebih lama akan menyebabkan semakin banyak senyawa kimia dengan titik didih tinggi yang terpoilimerasi, sehingga nilai bilangan ester pun akan semakin tinggi (Arpi, dkk., 2011). Hal ini sesuai dengan perbandingan nilai ester minyak nilam fraksinasi, dimana minyak nilam Fraksi 8 (7,9392) dengan waktu dan temperatur proses tertinggi memiliki nilai bilangan ester yang tertinggi pula, lalu diikuti dengan minyak nilam fraksi 7 (4,6651), dan minyak nilam fraksi $2(4,4371)$ dengan bilangan ester terkecil.

Nilai putaran optik dari minyak yang diujikan berbanding lurus dengan kadar patchouli alcohol dari masing-masing minyak nilam. Hal ini dikarenakan minyak nilam memiliki kecenderungan memutar ke arah kiri karena komponen alkohol nilam (patchouli alcohol) memiliki daya optik aktif ke kiri (-) yang lebih besar (Harimurti, dkk., 2012). Minyak nilam fraksi 8 dengan kandungan patchouli alcohol tertinggi memiliki nilai putaran optik sebesar $-82,30^{\circ}$, selanjutnya minyak nilam $100 \%$ dan minyak nilam fraksi 7 dengan kandungan patchouli alcohol yang tidak berbeda jauh, memiliki nilai putaran optik yang hampir sama, yaitu sebesar $-53,55^{\circ}(100 \%)$ dan $-52,95^{\circ}$ (fraksi 7). Sedangkan minyak nilamfraksi 2 memiliki nilai putaran optik terendah dengan nilai $-44,70^{\circ}$.

Hasil pengukuran kadar patchouli alcohol yang dilakukan dengan GC-MS pada penelitian Rosi (2016) dan Fathoni (2016) memperlihatkan bahwa minyak nilam $100 \%$, minyak nilam fraksi 7 , dan minyak nilam fraksi 8 telah memenuhi SNI, dengan kadar patchouli alcohol secara berturutturut sebesar $35,28 \%, 34,86 \%$ dan $55,59 \%$. Namun minyak nilam fraksi 2 , memiliki kadar patchouli alcohol dibawah 30\%, yaitu sebesar $25,62 \%$. Perbedaan kadar patchouli alcohol ini disebabkan oleh fraksinasi yang dilakukan pada minyak. Oleh 
karena itu, fraksi yang lebih rendah, seperti pada fraksi 2, lebih banyak mengandung komponen yang bertitik didih lebih rendah dari patchouli alcohol dan kandungan patchouli alcohol-nya masih rendah. Fraksi 8 yang memiliki kadar patchouli alcohol tertinggi, hal ini diduga karena komponen lain yang memiliki titik didih lebih rendah sudah terpisahkan pada fraksi-fraksi sebelumnya, sehingga dengan meningkatnya suhu dan tekanan pada proses fraksinasi, komponen yang terpisahkan adalah komponen dengan titik didih tinggi, diantarannya adalah patchouli alcohol (titik didih: $287^{\circ} \mathrm{C}$ ).

\section{Uji Aktivitas Antijamur}

Pengujian aktivitas antijamur dilakukan dengan menggunakan metode difusi agar sumuran. DDH yang terbentuk kemudian diamati dan diukur Gambar 2. Hasil pengukuran DDH kemudian dianalisis lebih lanjut dengan menggunakan RAL Faktorial. Tujuan digunakannya RAL Faktorial ini adalah untuk melihat pengaruh dari setiap faktor, yaitu faktor jamur dan faktor minyak nilam yang digunakan, beserta interaksi dari kedua faktor tersebut.

Setelah dilakukan pengujian data dengan RAL Faktorial, dan didapatkan hasil bahwa faktorfaktor dan interaksi terbukti memiliki pengaruh sangat nyata terhadap DDH yang didapatkan, dilakukan pengujian data lanjutan dilakukan karena. Pengujian data lanjutan terdiri dari dua uji: Uji Dunnet dan Uji Duncan. Uji Dunnet dilakukan untuk mengetahui perbedaan nyata antara pengujian aktivitas antijamur pada minyak nilam dan antibiotik kontrol positif (ketoconazole). Uji Duncan dilakukan untuk mengetahui kelompok dari setiap kombinasi dan mengetahui perbedaan nyata antar data.

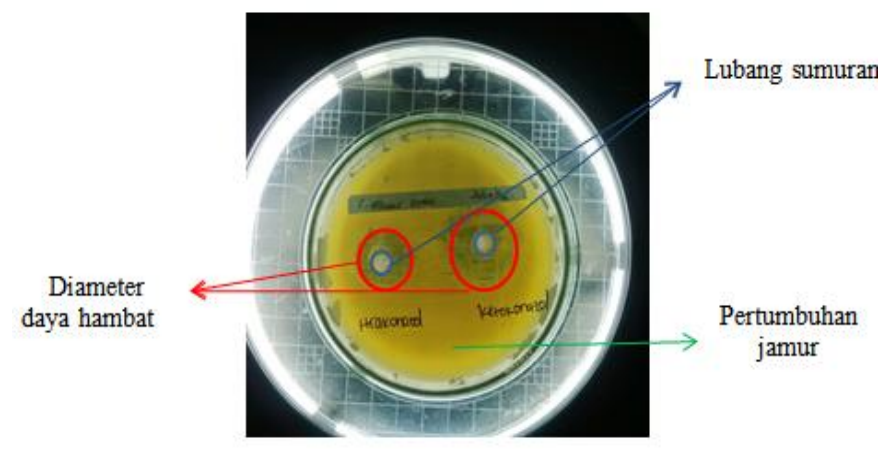

Gambar 2. Pembentukan diameter daya hambat jamur

Berdasarkan hasil analisis, didapatkan hasil bahwa semua sumber ragam pada Tabel Sidik Ragam (Lampiran 9) memiliki F-hitung yang lebih besar jika dibandingkan dengan F-tabel, baik pada taraf $5 \%$ maupun pada taraf $1 \%$. Nilai F-hitung yang lebih besar dari nilai F-tabel menunjukan bahwa kedua faktor dan interaksi dari kedua faktor tersebut memiliki pengaruh yang sangat nyata terhadap nilali DDH yang dihasilkan.

Pengaruh yang sangat nyata pada interaksi kedua faktor dapat dilihat dengan lebih jelas pada analisis dwi arah. Dalam bentu grafik, dapat dilihat respon faktor jenis jamur terhadap taraf jenis minyak nilam yang diujikan. Tidak adanya interaksi antar faktor diperlihatkan dengan garis respon yang sejajar. Sedangkan adanya interaksi antar faktor diperlihatkan dengan adanya perpotongan garis pada garis-garis respon. Grafik interaksi antar dua faktor tersebut dapat dilihat pada Gambar 3.

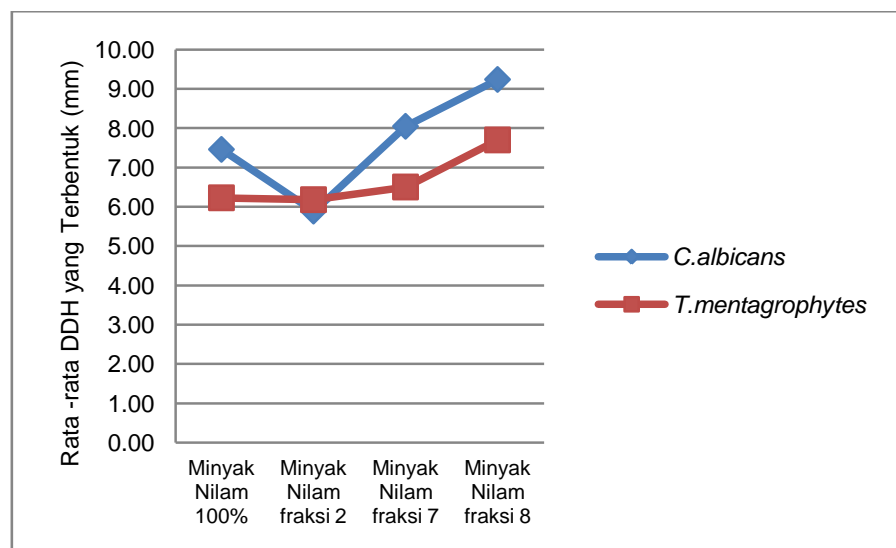

Gambar 3. Respon faktor jenis jamur terhadap taraf jenis minyak nilam 
Gambar 3 memperlihatkan adanya perpotongan garis yang menandakan adanya interaksi antar dua faktor. Pada Gambar 3, dapat dilihat bahwa DDH yang dihasilkan bergantung pada kombinasi antara kedua faktor. Jamur C.albicans tidak selalu memberikan nilai DDH yang terbaik. Kombinasi yang menunjukan aktivitas antijamur terbaik adalah kombinasi antara minyak nilam fraksi 8 dengan jamur C.albicans dengan nilai DDH sebesar 9,24 mm. Nilai DDH terendah dimiliki oleh kombinasi minyak nilam fraksi 2 dengan jamur C.albicans. Dari grafik, dapat dilihat bahwa Minyak nilam 100\%, minyak nilam fraksi 7, dan minyak nilam fraksi 8 menghasilkan DDH yang lebih besar pada jamur C.albicans. Minyak nilam fraksi 2 menghasilkan nilai DDH yang sedikit lebih baik pada T.mentargrophytes jika dibandingkan dengan hasilnya pada C.albicans. Karena perbedaan DDH dari minyak nilam fraksi 2 baik pada C.albicans maupun T.mentargrophytes yang cukup kecil, dan hasil pengujian lanjut Duncan dari kedua data tersebut yang menunjukkan bahwa keduanya beradadalam notasi yang sama (notasi c), maka dapat disimpulkan bahwa perbedaan jenis jamur tidak memberikan perbedaan yang nyata pada DDH minyak nilam fraksi 2. Hasil pengukuran DDH beserta hasil pengujian lanjutannya dapat dilihat pada Tabel 3.

Tabel 3. Hasil pengukuran DDH

\begin{tabular}{|c|c|c|}
\hline \multirow{2}{*}{$\begin{array}{c}\text { Jenis } \\
\text { Minyak } \\
\text { Nilam }\end{array}$} & \multicolumn{2}{|c|}{$\begin{array}{l}\text { Diameter Penghambatan } \\
\text { Pertumbuhan Jamur (mm) }\end{array}$} \\
\hline & C.albicans & T.mentargrophytes \\
\hline $100 \%$ & $7,46 \pm 0,29^{* b}$ & $6,23 \pm 0,23^{* c}$ \\
\hline Fraksi 2 & $5,89 \pm 0,36^{* c}$ & $6,18 \pm 0,49^{*} \mathrm{c}$ \\
\hline Fraksi 7 & $8,04 \pm 0,48^{* b}$ & $6,50 \pm 0,25^{*} \mathrm{c}$ \\
\hline Fraksi 8 & $9,24 \pm 0,62^{* a}$ & $7,70 \pm 0,32^{* b}$ \\
\hline Kontrol (+) & $29,49 \pm 0,56$ & $11,22 \pm 0,30$ \\
\hline Kontrol (-) & $(-)$ & $(-)$ \\
\hline
\end{tabular}

Keterangan: (-) menandakan Tidak terbentuk daerah penghambatan. *menunjukkan perbedaan nyata pada hasil uji Dunnet dan alfabet superscript merupakan notasi kelompok berdasarkan uji Duncan.

Hasil uji Duncan menunjukan bahwa hasil DDH pengujian dapat dibagi menjadi 3 notasi: $a, b$, dan c (Tabel 10). Jika dibandingkan hasil pengujian
Duncan pada setiap jamur, dapat dilihat bahwa 4 kombinasi minyak nilam terhadap jamur C.albicans dibagi menjadi 3 notasi. Sedangkan 4 kombinasi minyak nilam pada T.mentargrophytes hanya terbagi menjadi 2 notasi saja (b dan c).

Notasi a pada jamur C.albicans hanya ditempati oleh satu kombinasi faktor, yaitu kombinasi dengan minyak nilam fraksi 8 . Kombinasi faktor dengan nilai DDH terendah dimiliki oleh kombinasi C.albicans dengan minyak nilam fraksi 2 yang ditandai oleh notas $c$. Sedangkan kombinasi C.albicans dengan minyak nilam $100 \%$ dan minyak nilam fraksi 7 , meskipun memiliki nilai DDH yang berbeda, berada dalam satu notasi yang sama; notasi b. Hal ini menunjukan bahwa, meskipun kedua kombinasi ini memiliki nilai DDH yang berbeda, tapi keduanya tidak memiliki perbedaan hasil yang nyata dan dianggap berada dalam satu kelompok yang sama.

Hasil kombinasi minyak nilam dengan T.mentargrophytes hanya dikelompokkan pada 2 notasi yang berbeda. Notasi tertinggi dimiliki oleh kombinasi T.mentargrophytes dengan minyak nilam fraksi 8 pada notasi b. Sedangkan ketiga kombinasi lainnya berada dalam satu notasi, yaitu notasi c. Hal ini memperlihatkan bahwa dari keempat jenis minyak nilam yang diujikan pada T.mentargrophytes, yang memiliki perbedaan nyata dibandingkan dengan hasil lainnya hanyalah hasil uji dengan minyak fraksi 8. Sementara hasil lainnya, meskipun memiliki nilai yang berbeda, tetapi tidak berbeda nyata sehingga dikelompokan dalam satu notasi yang sama.

Dari pengelompokkan berdasarkan notasi uji Duncan dapat dilihat bahwa notasi tertinggi dari setiap jenis jamur dengan nilai DDH terbesar selalu dimiliki oleh pengujian antijamur pada minyak nilam fraksi 8; 9,24 mm (C.albicans) dan 7,70 mm (T.mentargrophytes). Minyak nilam 100\% dan minyak nilam fraksi 7 berada dalam satu notasi yang sama, baik pada pengujian terhadap C.albicans (notasi b) maupun T.mentargrophytes (notasi c). Sedangkan hasil uji pada minyak nilam fraksi 2 selalu berada pada notasi terendah dengan nilai DDH yang rendah pula. Penempatan notasi ini sangat dipengaruhi oleh besar nilai DDH dari setiap kombinasi. Dan nilai DDH pada setiap 
kombinasi terlihat berbanding lurus dengan kandungan patchouli alcohol pada jenis minyak nilam yang diujikan.

Hasil uji Dunnet dapat dilihat pada Tabel 3. Uji Dunnet merupakan uji yang membandingkan hasil pengujian yang dilakukan pada minyak nilam dan hasil pengujian pada zat kontrol. Zat kontrol positif yang digunakan pada penlitian ini merupakan ketoconazol krim 2\%, sementara kontrol negatif yang digunakan adalah aquades. Semua kombinasi perlakuan terbukti memiliki perbedaan yang nyata jika dibandingkan dengan kontrol positif. Hal ini bisa dikarenakan kandungan yang terdapat pada ketoconazole memiliki konsentrasi senyawa antifungal yang lebih tinggi jika dibandingkan dengan yang terdapat pada minyak nilam. Hal ini dapat dilihat pada tren DDH pada kedua jamur terhadap kadar patchouli alcohol yang berbanding lurus, yang berarti masih ada kemungkinan peningkatan hasil DDH pada kadar patchouli alcohol yang lebih tinggi.

Dari hasil pengamatan didapatkan hasil bahwa minyak nilam fraksi 8 dengan kandungan patchouli alcohol tertinggi $(54,59 \%)$ memiliki nilai DDH yang paling besar. Minyak nilam 100\% dan minyak nilam fraksi 7 memiliki kandungan patchouli alkohol yang tidak berbeda jauh, yaitu senilai $35,28 \%$ dan $34,86 \%$, terbukti tidak memiliki perbedaan nilai DDH yang nyata pada uji Duncan dengan berada pada notasi yang sama baik pada pengujian terhadap C.albicans maupun terhadap T.mentargrophytes. Dan minyak nilam fraksi 2 dengan kandungan patchouli alcohol terendah (25,62\%) memiliki nilai DDH terkecil pada pengujian terhadap kedua jenis jamur. Hasil penelitian ini sesuai dengan hasil penelitian Aisyah, dkk. (2008) yang menyatakan bahwa patchouli alcohol merupakan senyawa yang secara aktif menghambat pertubuhan mikroba uji. Patchouli alcohol sendiri merupakan salah satu senyawa sesquiterpen alcohol, yang termasuk ke dalam kategori senyawa hidrokarbon yang teroksigenasi. Sehingga dugaan bahwa patchouli alcohol merupakan senyawa aktif antijamur pada minyak nilam ini sesuai dengan pernyataan ElShazly dan Hussein (2004) bahwa senyawa seskuiterpen terutama seskuiterpen alkohol memiliki aktivitas penghambatan terhadap mikroba. Hasil penelitian ini sesuai dengan hipotesis dimana fraksinasi akan memengaruhi aktivitas antijamur pada minyak nilam. Semakin tinggi fraksi minyak, maka akan semakin tinggi kadar patchouli alcohol-nya. Tingginya kadar patchouli alcohol akan berbanding lurus dengan tingkat aktivitas antijamur dari minyak nilam tersebut, seperti yang dapat dilihat pada Gambar 3. Hal ini terjadi karena patchouli alcohol sendiri merupakan salah satu senyawa seskuiterpen yang menghambat pertumbuhan jamur dengan mengganggu membran sel dan disfungsi mitokondria (Freisleben dan Jaeger, 2014).

Perbandingan kombinasi faktor memperlihatkan bahwa kombinasi uji antara minyak nilam dengan $C$.albicans secara umum memperlihatkan hasil DDH dengan nilai yang lebih besar jika dibandingkan dengan hasil kombinasi minyak nilam dan T.mentargrophytes, dengan kombinasi jamur dengan minyak nilam fraksi 2 sebagai pengecualiannya. Kombinasi minyak nilam dengan C.albicans memperlihatkan hasil yang lebih beragam dengan kisaran DDH sebesar $5-9$ $\mathrm{mm}$. Sedangkan kombinasi minyak nilam dengan T.mentargrophytes memperlihatkan range $\mathrm{DDH}$ yang lebih kecil yaitu sebesar $6-7 \mathrm{~mm}$.

Perbedaan efektifitas antijamur pada C.albicans dan T.mentargrophytes ini juga pernah terjadi pada penelitian Pinto, dkk. (2006). Penelitian yang dilakukan adalah menguji aktivitas antijamur pada minyak atsiri Thymus pulegioides terhadap jamur dermatofit yang diantaranya adalah C.albicans dan T.mentargrophytes. Pada penelitian tersebut terlihat bahwa zat uji pada konsentrasi hambat minimumnya dapat mengurangi biosintesis ergosterol C.albicans sebesar 80 - 100\%. Sementara pada spesies Trichophyton, hanya sebesar $70 \%$.

Morita dan Nozawa (1985) juga mengalami perbedaan efektivitas zat uji pada C.albicans dan T.mentargrophytes. Penelitian yang dilakukan adalah pengujian efek antijamur terhadap biosintesis ergosterol pada C.albicans dan T.mentargrophytes dengan menggunakan zat uji miconazole. Dari hasil pengujian tersebut terlihat bahwa meskipun menggunakan zat uji yang sama, kedua jamur ini menunjukan hasil yang berbeda. Miconazole pada penellitian tersebut 
menyebabkan akumulasi lanosterol yang besar (50,5\%) pada C.albicans, sementara pada T.mentargrophytes, miconazole menyebabkan kenaikan radioaktivitas 24methylenedihydrolanosterol secara drastis (74.8\%).

Perbedaan hasil diantara kedua jamur ini juga diduga disebabkan oleh perbedaan kandungan protein pada kedua jamur. Wang, dkk. (2006) menyatakan bahwa T.rubrum berbagi $98 \%$ homology dengan T.mentargrophytes. Karenanya, hasil penelitian Martinez-rossi, dkk. (2008) yang menjelaskan bahwa squalene epoxidase (SE), yang merupakan katalis enzim pada retikulum endoplasma yang berperan penting dalam sintesis sterol, dari Saccharomyces cereviceae, C.albicans, dan Neurospora crassa memiliki 32 - 34 residu protein yang tidak ditemukan pada protein T.rubrum, Schizosaccharomyces pombe dan Homo sapiens dapat diduga sebagai penyebab lain terjadinya perbedaan efek antijamur pada C.albicans dan T.mentargrophytes.

Dari hasil penelitian yang didapat dan perbandingannya dengan literatur, maka perbedaan aktivitas antijamur pada kedua jenis jamur ini diduga disebabkan oleh perbedaan protein yang dimiliki oleh C.albicans dan T.mentargrophytes. Sehingga kedua jamur ini memiliki reaksi biosintesis yang berbeda atas penambahan zat antijamur pada proses pertumbuhannya.

\section{KESIMPULAN}

1. Keempat jenis minyak nilam yang diujikan menunjukan aktivitas positif sebagai agen T.mentargrophytes.

2. Kadar patchouli alcohol yang bervariasi dari hasil fraksinasi memiliki pengaruh yang signifikan terhadap hasil yang didapat. Dimana nilai DDH dan kadar patchouli alcohol berbanding lurus: semakin besar kadar patchouli alcohol pada minyak nilam, akan semakin besar pula nilai DDH yang dihasilkan.

\section{DAFTAR PUSTAKA}

Aisyah, Y., Hastuti, P., Sastrohamidjojo, H., Hidayat, C. 2008. Komposisi kimia dan sifat antibakteri minyak nilam (Pogostemon cablin). Majalah Farmasi Indonesia 19 (2008): 151-156

Armando, R. 2009. Memproduksi 15 Minyak Atsiri Berkualitas. Penebar Swadaya. Jakarta.

Arpi, N., Erika, C., Ermaya, D. 2011. Survey and Study on Yield and Quality of Patchouli Oil in Aceh Barat Daya District, Indonesia based on Original Are of Raw Mterials, Methods, and Length of Distillation. Annual International Conference Syiah Kuala University. 29-30 November.

Das, K., Gupta, N.K., Vijayabhaskar, S., dan Manjunath, U.M. 2011. Antimicrobial Potential of Patchouli Oil Cultivated Under Acidic Soil Zone of South India. Indian Journal of Novel Drug Delivery 3 (2011): $104-111$.

El-Shazly, A.M., dan Hussein, K.T., 2004. Chemical Analysis and Biological Activities of the Essential Oil of Teucrium leucocladum Boiss. (Lamiaceae). J. Biochemical Systematics and Ecology. 32 (2004): 665-674

Fathoni, R. P. 2016. Uji Aktivitas Antibakteri Pada Minyak Nilam Hasil Distilasi Fraksinasi Terhadap Bakteri Gram Positif (Staphylococcus epidermidis, Micrococcus luteus) Dan Bakteri Gram Negatif (Klebsiella pneumonia, Proteus mirabilis). [Skripsi]. Bandung: Universitas Padjadjaran.

Freiesleben, S. H. Dan Jager, A. K. 2014. Correlation between Plant Secondary Metabolites and Their Antifungal Mechanism - A Review. Med. Aromat Plants (2014): 3-12.

Guenther, E., Haagen-Smit, A. J., Langenai, E. E., Urdang, G. 2006. Minyak Atsiri. S. Ketaren (penerjemah). Jakarta: UI-Press

Harimurti, N., Soerawidjaja T. H., dan Sumangat D. 2012. Ekstraksi Minyak Nilam (Pogostemon cabin Benth) dengan Teknik Hidrofusi pada Tekanan 1-3 Bar. Balai Besar Penelitian dan Pengembangan Pascapanen Pertanian dan Program Studi Teknik Kimia Fakultas Teknologi Industri ITB. J. Pascapanen 9(1) (2012): 1-10

Jawetz, E., Melnick, J. L., and Adelberg, F. A. 2010. Medical Microbiology Twenty Fifth Edition. Atlanta. 
Kusumaningtyas, E. 2006. Mekanisme Infeksi C. albicans pada Permukaan Sel. Bogor: Balai Penelitian Veteriner

Martinez-rossi, N. M., N. T. A. Peres, A. Rossi. 2008. Antifungal Resistance Mechanism in Dermatophytes. Mycopathologia (2008): 369383

Morita, T. dan Nozawa, Y. 1985. Effects of Antifungal Agents on Ergosterol Biosynthesis in C. albicans and $T$. mentagrophytes: Differential Inhibitory Sites of $N$ aphthiomate and Miconazole. The Journal of Investigative Dermatology (1985): 434 - 437

Pinto, E., Pina-Vaz, C., Salgueiro, L., Goncalves, M. J., Costa-de-Oliveira, S., Cavaleiro, C., Palmeira, A., Rodrigues, A., dan Martinez-deOliveira, J. 2006. Antifungal activity of the essential oil of Thymus pulegioides on Candida, Aspergillus and dermatophyte species. Journal of Medical Microbiology (2006) 55; $1367-1373$

Ramya, H.G., Palanimuthu, V., dan Rachna, S. 2013. An Introduction to Patchouli (Pogostemon cablin Benth.) - A Medicinal and Aromatic Plant: It's Importance to Mankind. Agric. Eng Int: CIGR Journal 15 (2011): 243 250

Rosi, D. M. 2016. Uji Aktivitas Antibakteri Pada Minyak Nilam Hasil Distilasi Fraksinasi Terhadap Bakteri Gram Positif (Propionibacterium acnes, Sthaphylococcus aureus) Dan Bakteri Gram Negatif (Pseudomonas aeruginosa, Enterobacter aerogenes). [Skripsi]. Bandung: Universitas Padjadjaran.

Wang, L., et. all. 2006. Analysis of The Dermatophyte Trichophyton rubrum Expressed Sequence Tag. BMC Genomics (2006) 7:255 